\title{
Phytoplasma: Ecology and Genomic Diversity
}

\author{
Ing-Ming Lee, Dawn E. Gundersen-Rindal, and Assunta Bertaccini
}

First author: Molecular Plant Pathology Laboratory, USDA, ARS, Beltsville, MD 20705; second author: Insect Biocontrol Laboratory, USDA, ARS, Beltsville, MD 20705; and third author: Istituto di Patologia Vegetale, Università degli Studi, Via Filippo Re 8, 40126 Bologna, Italy. Accepted for publication 26 May 1998.

\begin{abstract}
Lee, I.-M., Gundersen-Rindal, D. E., and Bertaccini, A. 1998. Phytoplasma: Ecology and genomic diversity. Phytopathology 88:1359-1366.

The recent development of molecular-based probes such as mono- and polyclonal antibodies, cloned phytoplasma DNA fragments, and phytoplasma-specific primers for polymerase chain reaction (PCR) has allowed for advances in detection and identification of uncultured phytoplasmas (formerly called mycoplasma-like organisms). Comprehensive phylogenetic studies based on analysis of $16 \mathrm{~S}$ ribosomal RNA (rRNA) or both 16S rRNA and ribosomal protein gene operon sequences established the phylogenetic position of phytoplasmas as members of the class Mollicutes, and the revealed phylogenetic interrelationships among phytoplasmas formed a basis for their classification. Based on restriction fragment length polymor-
\end{abstract}

ABSTRACT

Phytoplasmas, formerly termed mycoplasma-like organisms, were discovered and described only 3 decades ago by a group of Japanese scientists (26), although the first phytoplasma (then called virus)-associated disease, aster yellows, was described by Kunkel (49) as early as 1926. These plant pathogens, ultrastructurally resembling members of the class Mollicutes (trivial name mycoplasma), are minute, cell wall-less bacteria that primarily inhabit phloem sieve elements. In nature, phytoplasma-associated plant diseases are transmitted and spread primarily by insect vectors belonging to the families Cicadelloidea (leafhoppers) and Fulgoroidea (planthoppers).

Attempts to culture phytoplasmas in cell-free media have failed. Until recently, the identities of phytoplasmas have remained unknown. During the last decade, the development of molecular-based tools such as mono- or polyclonal antibodies $(12,13,17,29,53)$, cloned phytoplasma DNA probes $(11,18,22,31,42,45,47,48,53-55$, 57,74 ), and in particular, phytoplasma-specific universal (generic) or phytoplasma group-specific polymerase chain reaction (PCR) primers designed on the basis of the highly conserved $16 \mathrm{~S}$ ribosomal RNA (rRNA) gene sequences $(2,24,25,28,35,39-44,58,59$, $66,67,75,81,88)$ made it possible for the first time to detect and identify a wide array of phytoplasmas believed to inflict diseases in hundreds of plant species (73). The ability to detect and identify a wide range of phytoplasmas associated with plants and insect vectors $(21,35,45,56,91)$ in nature has greatly facilitated studies on genomic diversity and ecology of phytoplasmas.

Several hundred phytoplasma-associated diseases have been reported since the discovery of phytoplasmas 3 decades ago (73). New disease outbreaks occur from time to time in various geographic regions. Numerous new phytoplasma strains have been

Corresponding author: I.-M. Lee; E-mail address: imlee@ asrr.arsusda.gov

Publication no. P-1998-1023-030

(C) 1998 The American Phytopathological Society phism (RFLP) analysis of PCR-amplified 16S rRNA gene sequences, phytoplasmas are currently classified into 14 groups and 38 subgroups that are consistent with groups delineated based on phylogenetic analysis using parsimony of $16 \mathrm{~S}$ rRNA gene sequences. In the past decades, numerous phytoplasma strains associated with plants and insect vectors have been identified using molecular-based tools. Genomic diversity of phytoplasma groups appears to be correlated with their sharing common insect vectors, host plants, or both in nature. The level of exchange of genetic information among phytoplasma strains in a given group is determined by three-way, vectorphytoplasma-plant interactions. A putative mechanism for the creation of new ecological niches and the evolution of new ecospecies is proposed.

Additional keywords: mixed infections, phytoplasma classification. identified in the last 4 years $(1,5-8,21-23,27,30,31,33,38,40,42,44$, 60-62,68-70,72,74,75,78,79,82,83,93,94,96,97), and a preliminary classification of known and new phytoplasma strains has revealed that phytoplasmas are more diverse than previously thought. However, little is known pertaining to new disease occurrence and spread, and the insect vector is often unknown. The lack of information on the ecology of phytoplasmas has hindered progress in finding natural vectors that transmit many important diseases and in designing efficient control measures for phytoplasma-associated diseases. With the recent development of molecular-based tools and sensitive detection procedures, we are now equipped to study the ecology of phytoplasmas. Some progress has already been made through studies of phytoplasma-plant relationships and interactions, but few studies have emphasized phytoplasma-vector relationships or interactions. In this communication, a review of information gathered from insect transmission studies conducted in the past decades $(4,5,10,14-16,20,32,34,49,73,77,85,90)$, studies of phytoplasma identities using molecular probes, and recent advances in phytoplasma-plant interrelationships provides some insights on the ecology of phytoplasmas. A putative model of evolution of new phytoplasma strains is also provided.

Recognition of diverse phytoplasma groups. The development of mono- and polyclonal antibodies and cloned DNA probes in the 1980s and 1990s led to the recognition of several distinct phytoplasma genomic clusters $(12,13,22,42,45,48,53-55,57)$. Southern hybridization and restriction fragment length polymorphism (RFLP) analyses using cloned DNA probes further differentiated phytoplasma strains within a given cluster into distinct subclusters (or types) $(33,42,47,48,57,67,74)$. For example, three subclusters (or types) were recognized within a collection of aster yellows phytoplasma strains, and seven subclusters were identified within the $\mathrm{X}$-disease genomic cluster $(33,54)$.

A preliminary phylogenetic study based on $16 \mathrm{~S}$ rRNA and ribosomal protein gene sequences by Lim and Sears $(63,64)$ was the 
first to reveal that a mycoplasma-like organism, the aster yellows phytoplasma, represented a new member of the class Mollicutes. Based on comprehensive phylogenetic analyses of 16S rRNA or both 16S rRNA and ribosomal protein gene sequences, the phylogenetic position of this new plant pathogen was clearly established $(37,84,89)$. The trivial name "phytoplasma" was officially adopted in 1994 to replace "mycoplasma-like organism". The established phylogenies formed a basis for classification of this uncultured plant pathogen. Attempts were made to identify and classify unknown phytoplasmas based on direct sequencing and analysis of phytoplasma $16 \mathrm{~S}$ rDNA or the $16 \mathrm{~S}$ to $23 \mathrm{~S}$ intergenic spacer region (46, $50,76)$. This approach is not always practical when a large number of unknown phytoplasmas are to be analyzed. RFLP analysis of PCR-amplified 16S rDNA sequences with a number of restriction enzymes was used by us and by others to differentiate various phytoplasmas on the basis of distinct RFLP patterns $(59,81)$. This procedure proved to be simple, reliable, and practical. The phytoplasma groups identified based on comprehensive RFLP analyses with sufficient restriction enzymes have been consistent with phylogenetic groups delineated based on sequence data $(37,59)$. Based on extensive RFLP analyses of phytoplasma 16S rDNA sequences, we previously identified 10 major phytoplasma groups and 15 subgroups (59). This classification scheme has since been expanded to include 14 groups and 38 subgroups (56) (Table 1). Finer subgroup differentiation within each major group has been attempted by using less-conserved sequences such as ribosomal protein gene clusters or the $16 \mathrm{~S}$ to $23 \mathrm{~S}$ rRNA intergenic spacer region, and additional subgroups have been identified $(36,38,71,88,95)$. Many of the subgroups identified through these approaches are consistent with genomic subclusters delineated previously based on DNA sequence homology studies with probe hybridizations $(33,58)$.

Host specificity of phytoplasmas. Both insects and plants are natural hosts of phytoplasmas. The host ranges in insect vectors and plants vary with phytoplasma strains. Some phytoplasmas have a low insect vector specificity, whereas others have a very high vector specificity. Examples of low insect vector specificity are California aster yellows phytoplasma (16SrI-B), which is transmitted by 24 species of leafhoppers; peach-X disease phytoplasma (16SrIII-A), which is transmitted by at least 15 species of leafhoppers; and clover phyllody (16SrI-C), which is transmitted by at least 9 species of leafhoppers $(72,89)$. Some phytoplasmas with a high insect vector specificity are beet leafhopper-transmitted virescence agent phytoplasma (16SrVI-A), American elm yellows phytoplasma (16SrV-A), sugarcane white leaf phytoplasma (16SrXI-B), sweetpotato witches' broom phytoplasma (16SrII-A), loofah witches' broom phytoplasma (16SrVIII-A), and pear decline phytoplasma (16SrX-C). These phytoplasmas appear to be transmitted by one or few vector species (90).

Plant host range for each phytoplasma in nature is determined largely by the number of natural insect vector species that are capable of transmitting the phytoplasma and by the feeding behaviors (mono-, oligo-, or polyphagus) of these vectors. Experimentally, some phytoplasmas can be transmitted by a polyphagus vector to a wide range of host plants $(15,32,34,49,73)$. For example, North American aster yellows phytoplasmas (16SrI-A, -B) were transmitted mostly by the polyphagus leafhopper Macrosteles fascifrons to 191 plant species belonging to 42 families, eastern X-disease (16SrIII-A) was transmitted by several polyphagous leafhoppers to 59 plant species belonging to 13 families, and BLTVA phytoplasma (16SrXI-A) was transmitted by Circulifer tenellus to 48 plant species belonging to 13 families $(32,73)$. In contrast, phytoplasmas such as American elm yellows, sweetpotato witches' broom, and pear decline, which are transmitted by mono- or oligophagus vectors (Scaphoideus luteolus, Orosius ryukyuensis, and Cacopsylla pyricola, respectively), have much narrower plant host ranges (77, 90). Susceptibility of plant(s) to a given phytoplasma and the vector feeding preference on plants largely determine the plant host range of a given phytoplasma.
Vector-phytoplasma-plant relationships. The phytoplasmaspecific molecular probes and sensitive assay procedures developed in the last decade have allowed for great advances in diagnostics for diseases caused by phytoplasmas. For the first time, the identities of phytoplasmas associated with many diseases in plants and insect vectors can be accurately determined $(1,5-8,19$ $21,23,27,29-31,33,38,39-43,45,46,48,59,60-62,67-72,74,76,78-84$, $86-88,93,94,96,97)$. The results revealed that the identities of phytoplasmas are inconsistent with the symptoms they induce on susceptible plants. Similar symptoms can be induced by various distinct types of phytoplasmas $(8,9,19,23,31,79,80,86,87)$, whereas several disparate symptom types can be induced by closely related phytoplasmas $(44,54,78,93,94)$. The ability to identify the phytoplasma associated with each disease or insect vector has greatly facilitated studies on vector-phytoplasma-plant relationships.

Based on insect transmission studies conducted in past decades and precise identification of associated phytoplasmas by molecular probes, it is known without ambiguity that many vectors can transmit more than one type of phytoplasma and that many plants can harbor two or more distinct phytoplasmas. For example, in North America, Colladonus montanus and Scaphytopious acutus delongi are common vectors that transmit both phytoplasmas associated with western X-disease and California aster yellows $(77,90)$. Similarly, Aphrodes bicinctus is the common vector that transmits North American aster yellows (16SrI-A) and clover phyllody (16SrI-C) (90). Aphrodes bicinctus is also the major vector that transmits clover phyllody and strawberry green petal (16SrI-C) and transmits with less efficiency stolbur disease (16SrXII-A) in southern Europe (10). In Australia, Orosius argentatus was reported to transmit legume little leaf, tomato big bud, lucerne witches' broom, virescence of tobacco, and potato purple top (34). However, these diseases may be caused by closely related phytoplasmas. In Europe, Macrosteles laevis transmits European aster yellows (16SrI-B), stolbur, clover phyllody, clover dwarf, primula yellows (16SrI-B), and onion yellows $(10,77)$. Although Macrosteles laevis is similar to the North American species Macrosteles fascifrons, the European species Macrosteles laevis was unable to transmit North American (16SrI-A) and California (16SrI-B) strains of aster yellows (10). Macrosteles fascifrons, however, can transmit both American strains of aster yellows and the European aster yellows. This may explain why the North American aster yellows phytoplasma strain (16SrI-A) has not been found in Europe, except for one rare example associated with gladiolus virescence (92).

Experimentally, each plant species has the potential to harbor more than one type of phytoplasma. Periwinkle, commonly used as a source plant to maintain phytoplasma culture, is able to harbor the majority of known phytoplasmas. However, in nature, the ability of a given plant species to harbor one or more types of phytoplasma is not entirely dependent on its susceptibility to phytoplasma infection. The insect vectors play an important role. The geographic distributions of various vectors and preferential host(s) of each vector are two major factors that determine whether a given plant species will be infected by single or multiple phytoplasmas. Although, in nature, many susceptible plant species appear to be infected each only by a specific phytoplasma, there are plant species that are infected by several distinct phytoplasmas. An example for the latter case is peach, which is infected by X-disease (16SrIII-A) in North America $(45,57)$, peach decline in China (16SrV-B) (I.-M. Lee, unpublished data), peach leaf chlorotic roll (16SrX-B) in the United States and Europe (38), and peach rosette (16SrI) (68) in Europe. Another two examples of this are clover, which is infected by clover phyllody, clover proliferation (16SrVI-A), clover yellow edge $(16 \mathrm{SrIII}-\mathrm{B})(53,54,57)$ (Table 1$)$, and clover dwarf (possibly belonging to 16SrI-B) (10); and grapevine, which is infected by flavescence dorée (16SrV-C) and grapevine yellows (16SrXII-A, -B) in Europe and Australia $(7,9,19,22,23,67,80)$. In most cases, each distinct phytoplasma is transmitted by a different vector in different geographic regions $(10,77)$. 
TABLE 1. Classification of phytoplasmas based on RFLP analyses of 16Sr RNA (16Sr) and ribosomal protein (rp) gene sequences

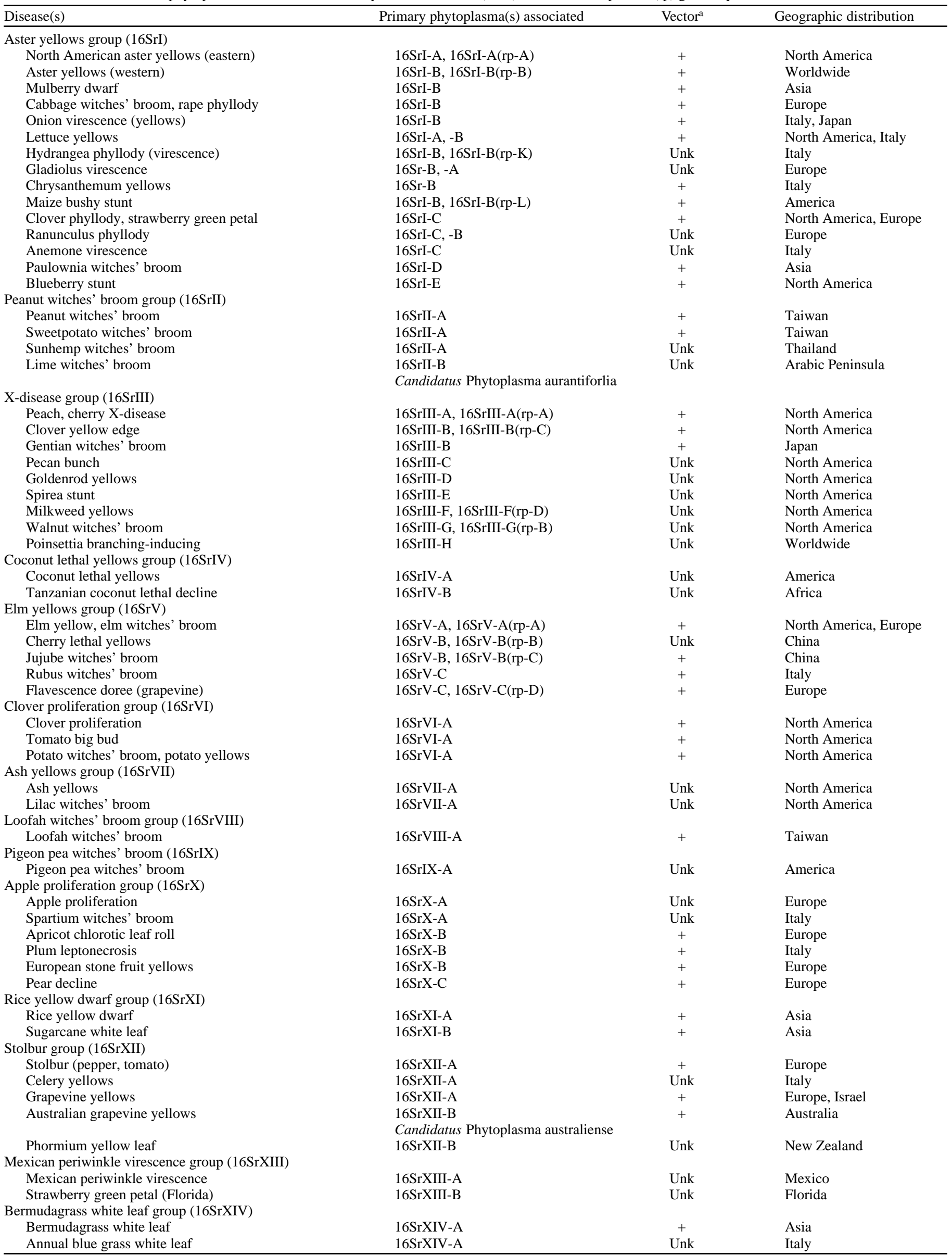

$\mathrm{a}^{+}=$Insect vector(s) has been reported; Unk $=$insect vector(s) has not been identified or reported. 
Recently, nested PCR assays using a universal primer pair followed by phytoplasma group-specific primer pairs revealed that a single plant often was infected by a predominant phytoplasma(s) and by one to several other phytoplasmas present in lower titers $(3,5,7,9,51,52,58,70)$. Via dodder transmission experiments, Loi et al. (65) demonstrated that two phytoplasmas were associated with plum trees affected by leptonecrosis. Mixed phytoplasma infections are seemingly more common than previously thought. It is interesting to note that phytoplasmas belonging to aster yellows and X-disease groups, which share common vectors in nature, are most frequently involved in mixed infections in North America. In Europe, host plants and vectors of aster yellows, stolbur, and elm yellows group phytoplasmas overlap, and these pathogens are commonly found in mixed infections (Tables 2 and 3). Little is known whether similar mixed infections in insect vectors occur as often as in plants. The leafhoppers Circulifer tenellus and Dalbulus elimantus are known to carry a phytoplasma and a spiroplasma, and each can transmit both pathogens. Because of overlapping host plants of many insect vectors (Table 2) and their capability to transmit more than one phytoplasma, it is not surprising that many of these vectors are able to carry dual or multiple phytoplasmas.

Genomic diversity: consequence of vector-phytoplasma-plant interactions. Overlapping vectors and plant hosts have allowed ample opportunities for phytoplasmas to interact with one another and to exchange their genetic information. When phytoplasmas share common vectors (Table 2) and host plants, the exchange of genetic information between or among these phytoplasmas in the pool (Fig. 1) can occur vertically and horizontally. As a result, a widely diverse phytoplasma group is formed with characteristics of continuous and wide genetic variations among its members. Aster yellow (16SrI) and X-disease (16SrIII) phytoplasma groups are examples of the two most diverse phytoplasma groups in nature (38) (Table 1). The aster yellows group comprises nine distinct rDNA RFLP subgroups with numerous strains that are distributed

TABLE 2. Vectors of phytoplasmas associated with various diseases ${ }^{\mathrm{a}}$

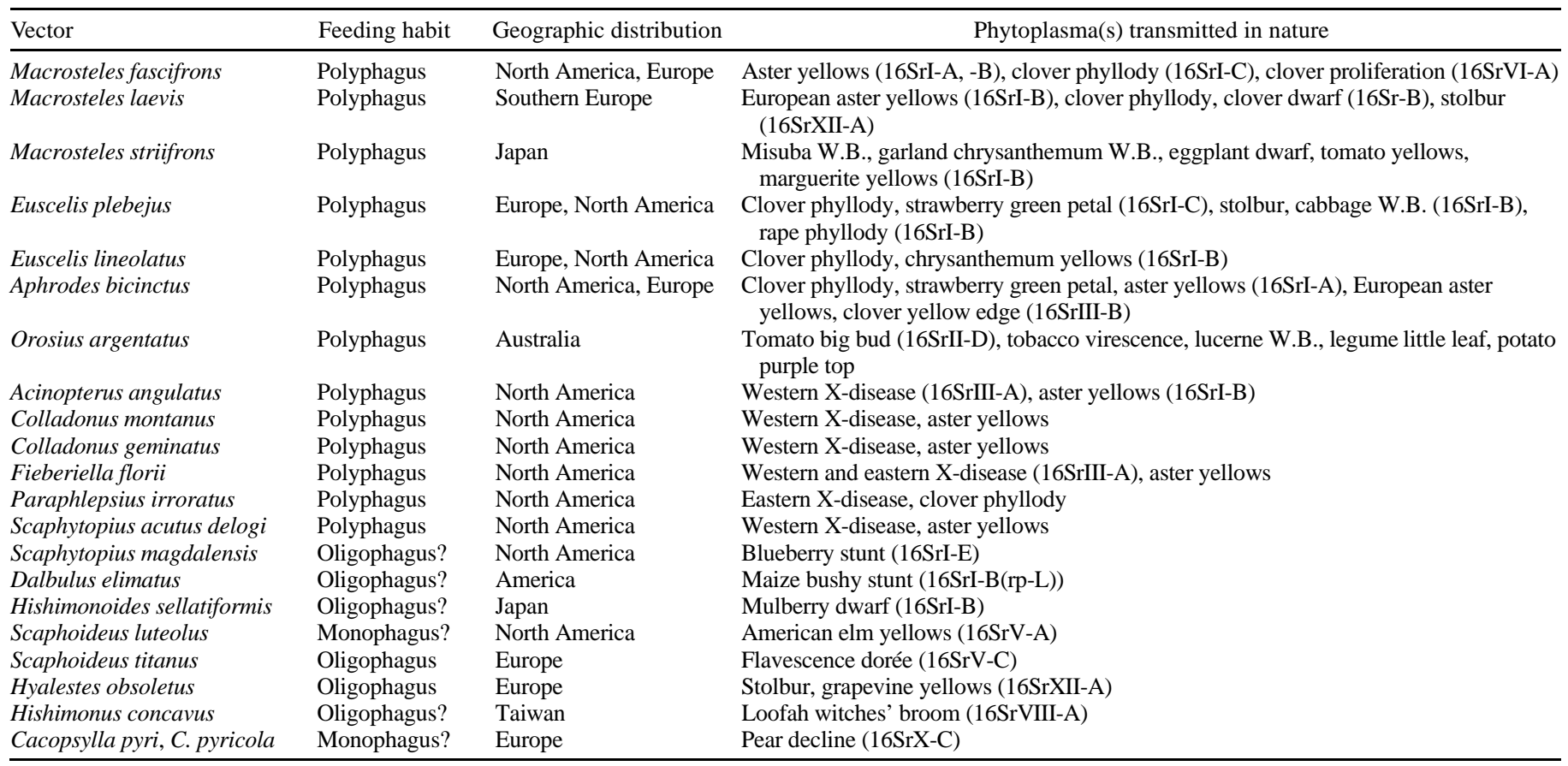

a Brcák (10), Grylls (34), Maixner et al. (67), and Tsai (90).

TABLE 3. Plants and insect vectors infected with dual or multiple phytoplasmas or mollicutes ${ }^{\mathrm{a}}$

\begin{tabular}{|c|c|c|}
\hline \multirow[b]{2}{*}{ Infected plants or insect vectors } & \multicolumn{2}{|c|}{ Phytoplasmas or mollicutes associated } \\
\hline & Primary & Minor \\
\hline \multicolumn{3}{|l|}{ Plants } \\
\hline Periwinkle infected with spirea stunt & 16SrIII-E & 16SrI-C \\
\hline Periwinkle infected with peach yellow leaf roll & 16SrIII-A & 16SrI-B \\
\hline Periwinkle infected with potato witches' broom & 16SrVI-A & 16SrI-B \\
\hline Clover infected with clover yellow edge & 16SrIII-B & 16SrI-B \\
\hline Horseweed infected with Erigeron yellows & 16 SrI-A & 16 SrIII-A \\
\hline Grapevine infected with grapevine yellows & $16 \mathrm{SrV}, 16 \mathrm{SrXII}-\mathrm{A}$ & 16SrI-B \\
\hline Apricot infected with apricot chlorotic leaf roll & $16 \mathrm{SrX}-\mathrm{B}$ & $16 \mathrm{SrI}-\mathrm{B}, 16 \mathrm{SrV}$ \\
\hline Nashi pear infected with pear decline & $16 \mathrm{SrX}-\mathrm{C}$ & $16 \mathrm{SrI}-\mathrm{B}, 16 \mathrm{SrV}$ \\
\hline Japanese plum infected with leptonecrosis & $16 \mathrm{SrX}-\mathrm{B}$ & 16SrI-B, 16SrX-C, 16SrV, 16SrXII-A \\
\hline Japanese plum (symptomless) & & 16SrX-C, 16SrI-B, 16SrV, 16SrIII \\
\hline European field elm infected with elm yellows & $16 \mathrm{SrV}-\mathrm{A}$ & 16SrI-B, 16SrXII-A \\
\hline Spartium infected with spartium witches' broom & $16 \mathrm{SrX}-\mathrm{A}$ & $16 \mathrm{SrV}-\mathrm{C}$ \\
\hline Hackberry with decline & $16 \mathrm{SrV}, 16 \mathrm{SrI}-\mathrm{B}$ & 16SrI-C, 16SrIII \\
\hline \multicolumn{3}{|l|}{ Insect vectors } \\
\hline Cacopsylla spp. from pear orchards & $16 \mathrm{SrX}-\mathrm{C}$ & 16SrI, 16SrIII \\
\hline Metcalfa pruinosa from orchards in Italy & $16 \mathrm{SrX}-\mathrm{B},-\mathrm{C}$ & 16SrI-B, 16SrXII-A \\
\hline Circulifer tenellus & 16SrVI-A, Spiroplasma citri & \\
\hline Dalbulus elimatus & 16SrI-B(rp-L), Spiroplasma kunkelii & \\
\hline
\end{tabular}

a Alma et al. (3), Bertaccini et al. (6; A. Bertaccini, unpublished data), Bianco et al. (9), Lee et al. (51,52,56,57), and Marcone et al. (70). 
worldwide, while the X-disease group comprises eight rDNA subgroups that are found in at least three continents (56). Genomic variations are also evident among members within some subgroups (e.g., 16SrI-B, -C) (38). In contrast, for those phytoplasmas belonging to the elm yellows group (16SrV), rice yellows dwarf (16SrXI), and loofah witches' broom group (16SrVIII) with narrow vector and host plant ranges, the primary exchange of genetic material primarily occurs vertically. Consequently, the degree of genetic variations is limited, and the phytoplasma group is less diverse. Some other phytoplasma groups showing a limited diversity are ash yellows (16SrVII) and coconut lethal yellows (16SrIV). The insect(s) that vector ash yellows is still unknown.

New ecological niches and new disease outbreaks. The genetic variation in the majority of phytoplasma subgroups seems correlated with the ecological isolation of these organisms (38) (Table 1), although some phytoplasma subgroups (e.g., 16SrI-A, -B) are associated with a wide range of plant and insect hosts (73). Phytoplasma strains in certain subgroups appear geographically isolated and exclusively associated with a narrow spectrum of plant and in- sect hosts, and often, their insect vectors are unknown. For example, paulownia witches' broom (16SrI-D), blueberry stunt (16SrI-E), maize bushy stunt (16SrI-Hrr-rp), pecan bunch (16SrIII-C), walnut witches' broom (16SrIII-F), and apple proliferation (16SrX-A) each exhibit specificity for a preferential plant host (Table 1). Isolation of a phytoplasma within a particular plant host may largely reflect insect vector feeding habits or plant host susceptibility to that phytoplasma. The vectors of paulownia witches' broom and maize bushy stunt are quite different from the common vectors shared by other members of the aster yellows group (90).

It is intriguing to speculate how these distinct ecological strains evolve and become isolated from the large strain pool of a given phytoplasma group. The insect vector may play an active role. A tentative mechanism for emergence of isolated subgroups in the aster yellows and X-disease phytoplasma groups is illustrated in Figure 1. Many insect vectors shared by phytoplasma strains in the aster yellows or X-disease phytoplasma groups are polyphagous. Preferential host plants are most frequently visited by these common vectors. A given host plant having dual or multiple phyto-

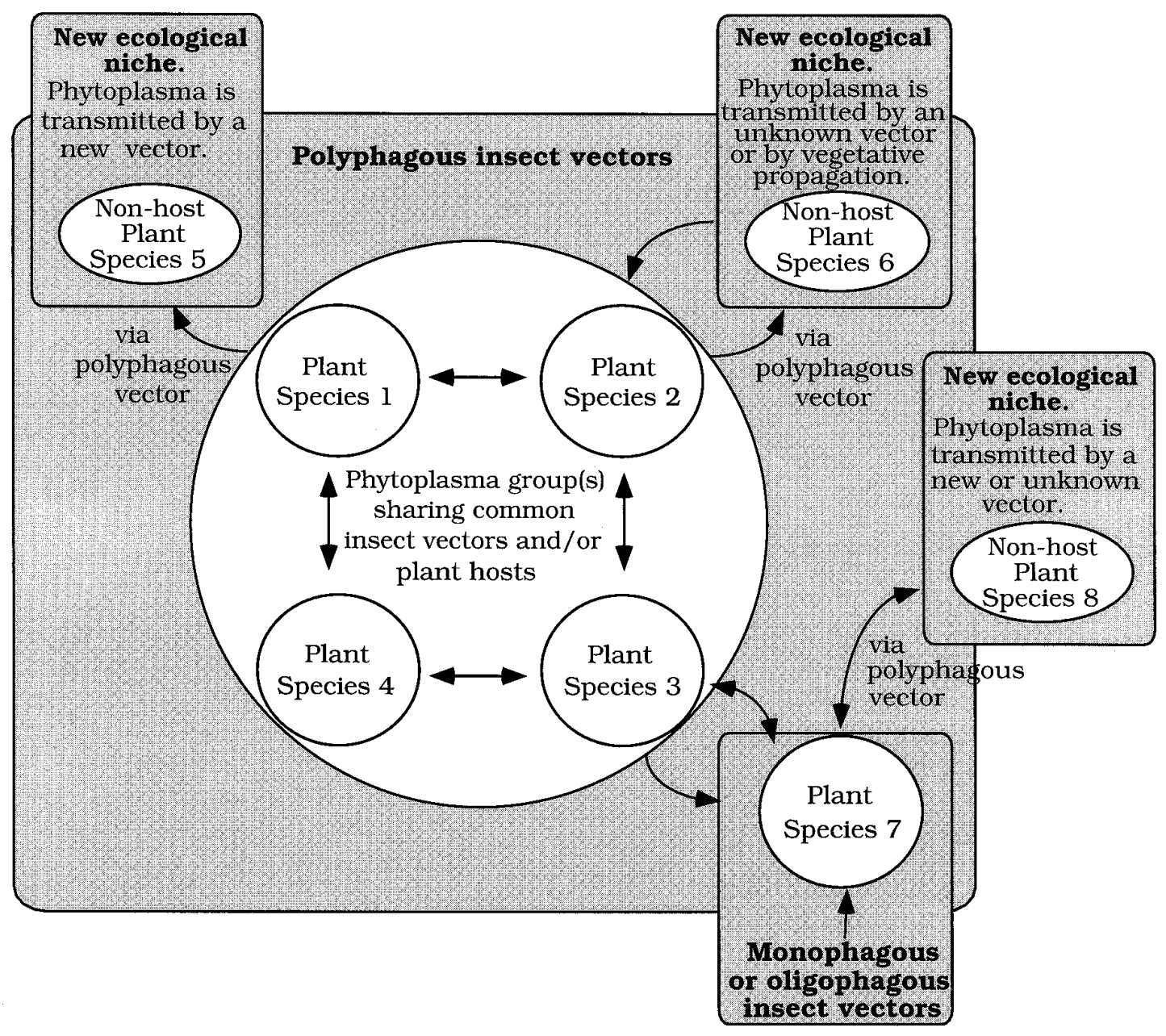

Fig. 1. A model of phytoplasma evolution that is driven by ecological constraints that allow new ecospecies to emerge. Some phytoplasmas such as strains in the aster yellows (AY) and X-disease phytoplasma groups share common polyphagous vectors and plant hosts. Over time, common host plants (plant species 1 , 2,3 , and 4) may become infected with two or more phytoplasmas (different subgroups of AY and X-disease groups). Because of different degrees of susceptibility to phytoplasma infection, these host plants or insect vectors sustain different population profiles of mixed phytoplasmas. Minor phytoplasmas in one host may predominate in another host. Interaction and horizontal exchange of genetic material between or among these phytoplasmas may occur. As a result, new cryptic phytoplasma strains may evolve. Occasionally, when the polyphagous vectors in the common pool voluntarily feed or are forced (in cases in which no other preferred plant hosts are available) to feed on nonpreferred host plants, some of the nonpreferred plant hosts (plant species 5, 6, or 7) may become infected with the phytoplasma(s) carried by these visiting vectors. The phytoplasmas associated with new hosts may be transmitted by new vectors (plant species 5) or unidentifiable visiting vectors. New ecological niches for the phytoplasmas are then created. The phytoplasmas in the new hosts will evolve independently from parent strains in the common pool. Phytoplasmas that have a narrow spectrum of host plants (e.g., plant species 7) most likely are transmitted by specific monoor oligophagous insect vectors. The latitude of genetic exchange among these phytoplasmas is limited. However, the host plants do not prevent polyphagous vectors from visiting them. A new ecological niche (plant species 8) for these phytoplasmas can be created through mediation by polyphagous insects. 
plasma infections may occur (plant species 1, 2, 3, or 4). Mixed infections are more common in places where the farming is intensive and mixed culture is routine. Mixed infections may also occur in insect vectors. Since susceptibility to phytoplasma infection varies with each plant and vector species, the population profiles of mixed phytoplasmas in these host plants or insect vectors are distinct from one another. Minor phytoplasmas in one host may predominate in another host. Normally, one or, in some cases, two primary phytoplasmas along with one or several minor (present in very low titers) phytoplasmas can be detected in a given host plant.

Occasionally, polyphagous insect vectors in the common pool may voluntarily feed or be forced to feed on nonhost plants, in cases in which no host plants are available. The nonhost plants will become infected if they are susceptible to the phytoplasma(s) carried by the visiting vectors. A new ecological niche for the phytoplasma is then created. The phytoplasma in this new host plant becomes isolated from the common pool shared by all members of the given phytoplasma group, and the latitude of genetic exchange from the strain pool greatly decreases. Since the genetic exchange for this isolated phytoplasma strain is different from the parental strain pool, the phytoplasma will evolve independently from the parent strain. The phytoplasma may be exposed to a new group of insect vectors (most likely mono- or oligophagous insects) and begin to establish a new biological and ecological circle (plant species 5). The phytoplasma in the new host may be transmitted by an unknown nonnative insect or by vegetative propagation (plant species 6). A new disease outbreak may be expected sometime during the course of forming new ecological niches, and the new vectors, if present (Fig. 1, plant species 5 or 8) then transmit and spread the disease. However, in nature, the insect vectors of many diseases (e.g., pecan bunch, walnut witches' broom, and apple proliferation) associated with isolated phytoplasmas remain unknown. The disease spread may largely depend on casually visiting vectors each season. The plants that are infected with the phytoplasmas are most likely not the preferred hosts of the visiting vectors. A good example for this mode of infection is citrus stubborn disease that is caused by Spiroplasma citri and transmitted by a casual visitor, the beet leafhopper Circulifer tenellus. The beet leafhopper feeds and completes its life cycle on numerous plants except citrus. Beet leafhoppers cannot survive on citrus plants. New ecological niches may likely be formed by a similar mechanism (primarily via polyphagus vectors) from relatively isolated niches in which plants (Fig. 1, plant species 7) are associated with less diverse phytoplasma groups and with monophagus or oligophagus insect vectors. Little is known about the ability of given insect vectors (e.g., oligophagus or polyphagus) to carry multiple phytoplasmas and transmit them. This information is necessary for interpreting any proposed mechanism for emergence of new phytoplasma strains.

Another plausible avenue for phytoplasmas to exploit new ecological niches is through long-distance movement (from continent to continent) and geographic isolation. Without strict quarantine inspection, phytoplasma-infected plant materials can be introduced through international exchange of germ plasms such as budwood, rootstock, tubers, etc., into new geographic regions where native vegetation and vector species are different from the region where the phytoplasmas were inadvertently transported. If all necessary elements (susceptible plant species and available vectors) for sustaining the phytoplasma(s) introduced are in place, a new ecological niche for the "imported" phytoplasma(s) is created. The newly introduced phytoplasmas have opportunities to interact with indigenous plants, vectors, and phytoplasmas.

\section{CONCLUSION}

The recent development of molecular-based tools, sensitive detection procedures, and classification schemes has allowed for great advances in the characterization and identification of phytoplasmas associated with plants and insect vectors. The identities of various phytoplasmas can now be accurately determined. This has facilitated studies on epidemiology of phytoplasma-associated diseases and ecology of phytoplasmas.

In the past decade, tremendous efforts have been focused on the characterization and identification of known and new phytoplasmas and have led to the establishment of a comprehensive classification scheme and to a proposal for a formal taxonomy of phytoplasmas. This progress has made it possible to study phytoplasma ecology. New insights are now attainable regarding which phytoplasmas to study and how these phytoplasmas operate in nature. Phytoplasmas cause diseases in several hundred plant species, and the number is growing each year. Little information is available about how various phytoplasmas become associated with plants and insect vectors. Each disease is the consequence of vector-phytoplasma-plant interactions. Better understanding of phytoplasma ecology is pertinent for the development of efficient control measures to combat disease. Some emphasis has been placed on phytoplasma-plant relationships. However, information concerning vector-phytoplasma and vector-plant relationships or interactions is very limited. This information is necessary for understanding most phytoplasma-associated diseases.

\section{LITERATURE CITED}

1. Ahrens, U., Lorenz, K.-H., and Seemüller, E. 1993. Genetic diversity among mycoplasmalike organisms associated with stone fruit diseases. Mol. Plant-Microbe Interact. 6:686-691.

2. Ahrens, U., and Seemüller, E. 1992. Detection of DNA of plant pathogenic mycoplasmalike organisms by a polymerase chain reaction that amplifies a sequence of the 16 S rRNA gene. Phytopathology 82:828-832.

3. Alma, A., Davis, R. E., Vibio, M., Danielli, A., Bosco, D., Arzone, A., and Bertaccini, A. 1996. Mixed infection of grapevines in northern Italy by phytoplasmas including $16 \mathrm{~S}$ rRNA RFLP subgroup $16 \mathrm{SrI}-\mathrm{B}$ strains previously unreported in this host. Plant Dis. 80:418-421.

4. Banttari, E. E., and Zeyen, R. J. 1979. Interactions of mycoplasmalike organisms and viruses in dually infected leafhoppers, planthoppers, and plants. Pages 327-347 in: Leafhopper Vectors and Plant Disease Agents. K. Maramorosch and K. F. Harris, eds. Academic Press, New York.

5. Bertaccini, A., Mittempergher, L., and Vibio, M. 1996. Identification of phytoplasmas associated with a decline of European hackberry (Celtis ourstralis). Ann. Appl. Biol. 128:245-253.

6. Bertaccini, A., Vibio, M., Davis, R. E., and Lee, I.-M. 1993. Molecular characterization of some mycoplasmalike organisms infecting plants in Italy. Petria Giornale Patol. Plante 3:9.

7. Bertaccini, A., Vibio, M., Shaff, D. A., Murari, E., Martini, M., and Danielli, A. 1997. Geographical distribution of elm yellows related phytoplasmas in grapevine flavescence dorée outbreaks in Veneto (Italy). Pages 57-58 in: Meeting Int. Council Study Viruses Virus-like Dis. Grapevine (ICVG), 12th. Ministerio da Agricoltura, do Densolvimento Rural e das Pescas (MADRP), Lisbona, Portugal.

8. Bertaccini, A., Vibio, M., and Stefani, E. 1995. Detection and molecular characterization of phytoplasmas infecting grapevine in Liguria (Italy). Phytopathol. Mediterr. 34:137-141.

9. Bianco, P. A., Davis, R. E., Prince, J. P., Lee, I.-M., Gundersen, D. E., Fortusini, A., and Belli, G. 1993. Double and single infections by aster yellows and elm yellows MLOs in grapevines with symptoms characteristic of flavescence doree. Riv. Patol. Veg. 3:69-82.

10. Brcák, J. 1979. Leafhopper and planthopper vectors of plant disease agents in central and southern Europe. Pages 97-154 in: Leafhopper Vectors and Plant Disease Agents. K. Maramorosch and K. F. Harris, eds. Academic Press, New York.

11. Chen, J. C., Chang, C. J., Jarret, R., and Gawel, N. 1992. Isolation and cloning of DNA fragments from mycoplasmalike organism associated with walnut witches'-broom disease. Phytopathology 82:306-309.

12. Chen, K. H., Redi, R. C., Loi, N., Maixner, M., and Chen, T. A. 1994. Identification and grouping of mycoplasmalike organisms associated with grapevine yellows and clover phyllody diseases based on immunological and molecular analyses. Appl. Environ. Microbiol. 60:1905-1913.

13. Chen, T.-A., Lei, J. D., and Lin, C. P. 1992. Detection and identification of plant and insect mollicutes. Pages 393-424 in: The Mycoplasmas, Vol. 5. R. F. Whitcomb and J. G. Tully, eds. Academic Press, New York.

14. Chiykowski, L. N. 1991. Vector-pathogen-host plant relationships of clover phyllody mycoplasmalike organism and the vector leafhopper Paraphlepsius irroratus. Can. J. Plant Pathol. 13:11-18.

15. Chiykowski, L. N., and Sinha, R. C. 1982. Herbaceous host plants of 
peach eastern X-disease agent. Can. J. Plant Pathol. 4:8-15.

16. Chiykowski, L. N., and Sinha, R. C. 1989. Differentiation of MLO disease by means of symptomatology and vector transmission. Zentralbl. Bakteriol. Hyg. (Suppl.) 20:280-287.

17. Clark, M. F., Morton, A., and Buss, S. L. 1989. Preparation of MLO immunogens from plants and a comparison of polyclonal and monoclonal antibodies made against primula yellows MLO-associated antigens. Ann. Appl. Biol. 114:111-124.

18. Daire, X., Boudon-Padieu, E., Berville, A., Schneider, B., and Caudwell, A. 1992. Cloned DNA probes for detection of grapevine flavescence doree mycoplasma-like organism (MLO). Ann. Appl. Biol. 121:95-103.

19. Daire, X., Claire, D., Larrue, J., Boudon-Padieu, E., Alma, A., Arzone, A., Carraro, L., Osler, R., Refatti, E., Granata, G., Credi, R., Tanne, E., Pearson, R., and Caudwell, A. 1993. Occurrence of diverse MLOs in tissues of grapevine affected by grapevine yellows in different countries. Vitis 32:247-248.

20. Davies, D. L., Barbara, D. J., and Clark, M. F. 1995. The detection of MLOs associated with pear decline in pear trees and pear psyllids by polymerase chain reaction. Acta Hortic. 386:484-488.

21. Davies, D. L., Guise, C. M., Clark, M. F., and Adams, A. N. 1992. Parry's disease of pears is similar to pear decline and is associated with mycoplasmalike organisms transmitted by Cacopsylla pyricola. Plant Pathol. 41:195-203.

22. Davis, R. E., Dally, E. L., Bertaccini, A., Lee, I.-M., Credi, R., Osler, R., Savino, V., Carraro, L., Di Terlizzi, B., and Barba, M. 1993. Restriction fragment length polymorphism analyses and dot hybridizations distinguish mycoplasmalike organisms associated with flavescence dorée and southern European grapevine yellows disease in Italy. Phytopathology 83:772-776.

23. Davis, R. E., Dally, E. L., Gundersen, D. E., Lee, I.-M., and Habili, N. 1997. "Candidatus Phytoplasma australiense", a new phytoplasma taxon associated with Australian grapevine yellows. Int. J. Syst. Bacteriol. 47: 262-269.

24. Davis, R. E., and Lee, I.-M. 1993. Cluster-specific polymerase chain reaction amplification of $16 \mathrm{~S}$ rDNA sequences for detection and identification of mycoplasmalike organisms. Phytopathology 83:1008-1011.

25. Deng, S., and Hiruki, C. 1991. Amplification of 16S rRNA genes from culturable and non-culturable mollicutes. J. Microbiol. Methods 14:53-61.

26. Doi, Y. M., Teranaka, M., Yora, K., and Asuyama, H. 1967. Mycoplasma or PLT-group-like microorganisms found in the phloem elements of plants infected with mulberry dwarf, potato witches' broom, aster yellows, or paulownia witches' broom. Ann. Phytopathol. Soc. Jpn. 33:259-266.

27. Firraro, G. 1996. Molecular characterization of a phytoplasma causing phyllody in clover and other herbaceous hosts in northern Italy. Eur. J. Plant Pathol. 102:817-822.

28. Firrao, G., Gobbi, E., and Locci, R. 1993. Use of polymerase chain reaction to produce oligonucleotide probes for mycoplasmalike organisms. Phytopathology 83:602-607.

29. Fos, A., Danet, J. L., Zreik, L., Garnier, M., and Bové, J. M. 1992. Use of a monoclonal antibody to detect the stolbur mycoplasmalike organism in plants and insects and to identify a vector in France. Plant Dis. 76: 1092-1096.

30. Gibb, K. S., Persley, D. M., Schneider, B., and Thomas, J. E. 1996. Phytoplasmas associated with papaya diseases in Australia. Plant Dis. 80:174-178.

31. Gibb, K. S., Padovan, A. C., and Mogen, B. D. 1995. Studies on sweet potato little-leaf phytoplasma detected in sweet potato and other plant species in northern Australia. Phytopathology 85:169-174.

32. Golino, D. A., Oldfield, G. N., and Gumpf, D. J. 1989. Experimental hosts of the beet leafhopper-transmitted virescence agent. Plant Dis. 73:850-854.

33. Griffiths, H. M., Gundersen, D. E., Sinclair, W. A., Lee, I.-M., and Davis, R. E. 1994. Mycoplasmalike organisms from milkweed, goldenrod, and spirea represent two new 16S rRNA subgroups and three new strain subclusters related to peach X-disease. Can. J. Plant Pathol. 16: 255-266.

34. Grylls, N. E. 1979. Leafhopper vectors and the plant disease agents they transmit in Australia. Pages 179-213 in: Leafhopper Vectors and Plant Disease Agents. K. Maramorosch and K. Harris, eds. Academic Press, New York.

35. Gundersen, D. E., and Lee, I.-M. 1996. Ultrasensitive detection of phytoplasmas by nested-PCR assays using two universal primer pairs. Phytopathol. Mediterr. 35:114-151.

36. Gundersen, D. E., Lee, I.-M., and Davis, R. E. 1994. RFLP analyses of ribosomal protein genes reveal strain diversity in MLO 16S rRNA groups I and III. (Abstr.) Phytopathology 84:1128.

37. Gundersen, D. E., Lee, I.-M., Rehner, S. A., Davis, R. E., and Kingsbury, D. T. 1994. Phylogeny of mycoplasmalike organisms (phytoplasmas): A basis for their classification. J. Bacteriol. 176:5244-5254.

38. Gundersen, D. E., Lee, I.-M., Schaff, D. A., Harrison, N. A., Chang, C.
J., Davis, R. E., and Kingsbury, D. T. 1996. Genomic diversity and differentiation among phytoplasma strains in 16S rRNA group I (aster yellows and related phytoplasmas) and III (X-disease and related phytoplasmas). Int. J. Syst. Bacteriol. 46:64-75.

39. Harrison, N. A., Tsai, J. H., Ebbert, M. A., and Kramer, J. B. 1996. PCR assay for detection of the phytoplasma associated with maize bushy stunt disease. Plant Dis. 80:263-269.

40. Harrison, N. A., Richardson, P. A., Jones, P., Tymon, A. M., Eden-Green, S. J., and Mpunami, A. A. 1994. Comparative investigation of MLOs associated with Caribbean and African coconut lethal decline diseases by DNA hybridization and PCR assays. Plant Dis. 78:507-511.

41. Harrison, N. A., Richardson, P. A., Kramer, J. B., and Tsai, J. H. 1994. Detection of the mycoplasmalike organism associated with lethal yellowing disease of palms in Florida by polymerase chain reaction. Plant Pathol. 43:998-1008.

42. Hibben, C. R., Sinclair, W. A., Davis, R. E., and Alexander, III, J. H. 1991. Relatedness of mycoplasmalike organisms associated with ash yellows and lilac witches'-broom. Plant Dis. 75:1227-1230.

43. Jarausch, W., Cellaret, C., Dosba, F., and Bobé, J. M. 1994. Differentiation of mycoplasmalike organisms (MLOs) in European fruit trees by PCR using specific primers derived from the sequence of a chromosomal fragment of the apple proliferation MLO. Appl. Environ. Microbiol. 60:2916-2923.

44. Jomantiene, R., Davis, R. E., Mass, J., and Dally, E. L. 1998. Classification of new phytoplasmas associated with diseases of strawberry in Florida based on analysis of $16 \mathrm{~S}$ rRNA and ribosomal protein gene operon sequences. Int. J. Syst. Bacteriol. 48:269-277.

45. Kirkpatrick, B. C., Fisher, G. A., Fraser, J. D., and Purcell, A. H. 1987. Cloning and detection of DNA from a nonculturable plant pathogenic mycoplasmalike organism. Science 238:197-200.

46. Kirkpatrick, B. C., Smart, C. D., Gardner, S. L., Gao, J.-L., Ahrens, U., Maurer, R., Schneider, S., Lorenz, K.-H., Seemuller, E., Harrison, N. A., Namba, S., and Daire, X. 1994. Phylogenetic relationships of plant pathogenic MLOs established by $16 / 23 \mathrm{~S}$ rDNA spacer sequences. IOM Lett. 3:228-229.

47. Kison, H., Schneider, B., and Seemüller, E. 1994. Restriction fragment length polymorphisms within the apple proliferation mycoplasmalike organism. J. Phytopathol. 141:395-401.

48. Ko, H. C., and Lin, C. P. 1994. Development and application of cloned DNA probes for a mycoplasmalike organism associated with sweetpotato witches'-broom. Phytopathology 84:468-473.

49. Kunkel, L. O. 1926. Studies on aster yellows. Am. J. Bot. 23:646-705.

50. Kuske, C. R., and Kirkpatrick, B. C. 1992. Phylogenetic relationships between the western aster yellows mycoplasmalike organisms and other prokaryotes established by $16 \mathrm{~S}$ rRNA gene sequence. Int. J. Syst. Bacteriol. 42:226-233.

51. Lee, I.-M., Bertaccini, A., Vibio, M., and Gundersen, D. E. 1995. Detection of multiple phytoplasmas in perennial fruit trees with decline symptoms in Italy. Phytopathology 85:728-735.

52. Lee, I.-M., Bertaccini, A., Vibio, M., Gundersen, D. E., Davis, R. E., Mittempergher, L., Conti, M., and Gennari, F. 1995. Detection and characterization of phytoplasmas associated with disease in Ulmus and Rubus in northern and central Italy. Phytopathol. Mediterr. 34:174-183.

53. Lee, I.-M., and Davis, R. E. 1992. Mycoplasmas which infect plants and insects. Pages 379-390 in: Mycoplasmas: Molecular Biology and Pathogenesis. J. Maniloff, R. N. McElhansey, L. R. Finch, and J. B. Baseman, eds. American Society for Microbiology, Washington, DC.

54. Lee, I.-M., Davis, R. E., Chen, T.-A., Chiykowski, L. N., Fletcher, J., Hiruki, C., and Schaff, D. A. 1992. A genotype-based system for identification and classification of mycoplasmalike organisms (MLOs) in the aster yellows MLO strain cluster. Phytopathology 82:977-986.

55. Lee, I.-M., Davis, R. E., Sinclair, W. A., DeWitt, N. D., and Conti, M. 1993. Genetic relatedness of mycoplasmalike organisms detected in $U l$ mus spp. in the United States and Italy by means of DNA probes and polymerase chain reactions. Phytopathology 83:829-833.

56. Lee, I.-M., Gundersen-Rindal, D. E., Davis, R. E., and Bartoszyk, I. M. 1998. Revised classification scheme of phytoplasmas based on RFLP analyses of 16S rRNA and ribosomal protein gene sequences. Int. J. Syst. Bacteriol. 48:1153-1169.

57. Lee, I.-M., Gundersen, D. E., Davis, R. E., and Chiykowski, L. N. 1992. Identification and analysis of a genomic strain cluster of mycoplasmalike organisms associated with Canadian peach (eastern) X-disease, western X-disease, and clover yellow edge. J. Bacteriol. 174:6694-6698.

58. Lee, I.-M., Gundersen, D. E., Hammond, R. W., and Davis, R. E. 1994. Use of mycoplasmalike organism (MLO) group-specific oligonucleotide primers for nested-PCR assays to detect mixed-MLO infections in a single host plant. Phytopathology 84:559-566.

59. Lee, I.-M., Hammond, R. W., Davis, R. E., and Gundersen, D. E. 1993 Universal amplification and analysis of pathogen 16S rDNA for classification and identification of mycoplasmalike organisms. Phytopathology 
83:834-842.

60. Lee, I.-M., Klopmeyer, M., Bartoszyk, I. M., Gundersen-Rindal, D. E., Chou, T.-S., Thomson, K. L., and Eisenreich, R. 1997. Phytoplasma induced free-branching in commercial poinsettia cultivars. Nature Biotechnol. 15:178-182.

61. Lee, I.-M., Pastore, M., Vibio, M., Danielli, A., Attathom, S., Davis, R. E., and Bertaccini, A. 1997. Detection and characterization of phytoplasma associated with annual blue grass (Poa annua) white leaf in southern Italy. Eur. J. Plant Pathol. 103:251-254.

62. Lee, I.-M., Zhu, S., Gundersen, D. E., Zhang, C., and Hadidi, A. 1995. Detection and identification of a new phytoplasma associated with cherry lethal yellows in China. (Abstr.) Phytopathology 85:1179.

63. Lim, P. O., and Sears, B. B. 1989. 16S rRNA sequence indicates that plant-pathogenic mycoplasmalike organisms are evolutionarily distinct from animal mycoplasmas. J. Bacteriol. 171:5901-5906.

64. Lim, P.-O., and Sears, B. B. 1992. Evolutionary relationships of a plantpathogenic mycoplasmalike organism and Acholeplasma laidlawii deduced from two ribosomal protein gene sequences. J. Bacteriol. 174: 2606-2611.

65. Loi, N., Carraro, L., Musetti, R., Pertot, I., and Osler, R. 1995. Dodder transmission of two different MLOs from plum trees affected by "leptonecrosis". Acta Hortic. 386:465-470.

66. Lorenz, K.-H., Schneider, B., Ahrens, U., and Seemüller, E. 1995. Detection of the apple proliferation and pear decline phytoplasmas by PCR amplification of ribosomal and nonribosomal DNA. Phytopathology 85: 771-776.

67. Maixner, M., Ahrens, U., and Seemüller, E. 1995. Detection of the German grapevine yellows (Vergibungskrankheit) MLO in grapevine, alternative hosts, and a vector by a specific PCR procedure. Eur. J. Plant Pathol. 101:241-250.

68. Marcone, C., DiSerio, F., and Ragozzino, A. 1995. Peach rosette: A disease associated with mycoplasma-like organisms. Acta Hortic. 386: 471-479.

69. Marcone, C., Ragozzino, A., Schneider, B., Lauer, U., Smart, C. D., and Seemüller, E. 1996. Genetic characterization and classification of two phytoplasmas associated with spartium witches'-broom disease. Plant Dis. 80:365-371.

70. Marcone, C., Ragozzino, A., and Seemüller, E. 1996. Detection of an elm yellows-related phytoplasma in eucalyptus trees affected by littleleaf disease in Italy. Plant Dis. 80:669-673.

71. Marcone, C., Ragozzino, A., and Seemüller, E. 1997. Identification and characterization of the phytoplasma associated with elm yellows in southern Italy and its relatedness to other phytoplasmas of the elm yellows group. Eur. J. Forest Pathol. 27:45-54.

72. Mäurer, R., Seemüller, E., and Sinclair, W. A. 1993. Genetic relatedness of mycoplasmalike organisms affecting elm, alder, and ash in Europe and North America. Phytopathology 83:971-976.

73. McCoy, R. E., Caudwell, A., Chang, C. J., Chen, T. A., Chiykowski, L. N., Cousin, M. T., Dale, J. L., de Leeuw, G. T. N., Golino, D. A., Hackett, K. J., Kirkpatrick, B. C., Marwitz, R., Petzold, H., Sinha, R. H., Sugiura, M., Whitcomb, R. F., Yang, I. L., Zhu, B. M., and Seemüller, E. 1989. Plant diseases associated with mycoplasmalike organisms. Pages 545560 in: The Mycoplasmas, Vol. 5. R. F. Whitcomb and J. G. Tully, eds. Academic Press, New York.

74. Nakashima, K., Kato, S., Iwanami, S., and Murata, N. 1993. DNA probes reveal relatedness of rice yellow dwarf mycoplasmalike organisms (MLOs) and distinguish them from other MLOs. Appl. Environ. Microbiol. 59: 1206-1212.

75. Namba, S., Kato, S., Iwanami, S., Oyaizu, H., Shiozawa, H., and Tsuchizaki, T. 1993. Detection and differentiation of plant-pathogenic mycoplasmalike organisms using polymerase chain reaction. Phytopathology 83:786-791.

76. Namba, S., Oyaizu, H., Kato, S., Iwanami, S., and Tsuchizaki, T. 1993. Phylogenetic diversity of phytopathogenic mycoplasmalike organisms. Int. J. Syst. Bacteriol. 43:461-467.

77. Nielson, M. W. 1979. Taxonomic relationships of leafhopper vectors of plant pathogens. Pages 3-27 in: Leafhopper Vectors and Plant Disease Agents. K. Maramorosch and K. F. Harris, eds. Academic Press, New York.

78. Okuda, S., Prince, J. P., Davis, R. E., Dally, E. L., Lee, I.-M., Mogen, B., and Kato, S. 1997. Two groups of phytoplasmas from Japan distinguished on the basis of amplification and restriction analysis of $16 \mathrm{~S}$
rDNA. Plant Dis. 81:301-305.

79. Padovan, A. C., Gibb, K. S., Bertaccini, A., Bonfiglioli, R. E., Magnet, P. A., and Sears, B. B. 1995. Molecular detection of the Australian grapevine yellows phytoplasma and comparison with grapevine yellows phytoplasmas from Italy. Aust. J. Grape Wine Res. 1:25-31.

80. Prince, J. P., Davis, R. E., Wolf, T. K., Lee, I.-M., Mogen, B. D., Dally, E. L., Bertaccini, A., Credi, R., and Barba, M. 1993. Molecular detection of diverse mycoplasmalike organisms (MLOs) associated with grapevine yellows and their classification with aster yellows, X-disease, and elm yellows MLOs. Phytopathology 83:1130-1137.

81. Schneider, B., Ahrens, U., Kirkpatrick, B. C., and Seemüller, E. 1993. Classification of plant-pathogenic mycoplasma-like organisms using restriction-site analysis of PCR-amplified 16S rDNA. J. Gen. Microbiol. 139:519-527.

82. Schneider, B., Cousin, M. T., Klinkong, S., and Seemüller, E. 1995. Taxonomic relatedness and phylogenetic positions of phytoplasmas associated with diseases of faba bean, sunhemp, sesame, soybean, and eggplant. Z. Pflanzenkr. Pflanzenschutz 102:225-232.

83. Schneider, B., and Gibb, K. S. 1997. Detection of phytoplasmas in declining pears in southern Australia. Plant Dis. 81:254-258.

84. Seemüller, E., Schneider, B., Mäurer, R., Ahrens, U., Daire, X., Kison, H., Lorenz, K.-H., Firrao, G., Avinent, L., Sears, B. B., and Stackebrandt, E. 1994. Phylogenetic classification of phytopathogenic mollicutes by sequence analysis of 16S ribosomal DNA. Int. J. Syst. Bacteriol. 44:440-446.

85. Shao, P. H., Hung, J. F., Tung, D. C., Pan, C. H., Shen, C. Y., and Chen, T. Y. 1982. Studies on the insect vector of paulownia witches'-broom. I. Transmission by Halyomorpha halys (Stal) and electron microscope observation. Shandong Forest Sci. Technol. 1:207-208.

86. Shaw, M. E., Kirkpatrick, B. C., and Golino, D. A. 1991. Causal agent of tomato big bud disease in California is the beet leafhopper transmitted virescence agent. (Abstr.) Phytopathology 81:1210.

87. Sinclair, W. A., Griffiths, H. M., and Lee, I.-M. 1994. Mycoplasmalike organisms as causes of slow growth and decline of trees and shrubs. J. Aboric. 20:176-189.

88. Smart, C. D., Schneider, B., Blomquist, C. L., Guerra, L. J., Harrison, N. A., Ahrens, U., Lorenz, K.-H., Seemüller, E., and Kirkpatrick, B. C. 1996. Phytoplasma-specific PCR primers based on sequences of $16 \mathrm{~S}$ 23S rRNA spacer region. Appl. Environ. Microbiol. 62:2988-2993.

89. Toth, K. F., Harrison, N. A., and Sears, B. B. 1994. Phylogenetic relationships among members of the class Mollicutes deduced from rps3 gene sequences. Int. J. Syst. Bacteriol. 44:119-124.

90. Tsai, J. H. 1979. Vector transmission of mycoplasmal agents of plant diseases. Pages 265-307 in: The Mycoplasmas, Vol. 3. R. E. Whitcomb and J. G. Tully, eds. Academic Press, New York.

91. Vega, F. E., Davis, R. E., Barbosa, P., Dally, E. L., Purcell, A. H., and Lee, I.-M. 1993. Detection of a plant pathogen in a nonvector insect species by the polymerase chain reaction. Phytopathology 83:621-624.

92. Vibio, M., Bertaccini, A., and Gennari, F. 1994. Molecular characterization of mycoplasmalike organisms infecting gladiolus crops. Pages 149150 in: 5th Congress of University and Biotechnology Innovation. CIB (Consorzio Interuniversitario Biotecnologie), Bologna, Italy.

93. Vibio, M., Bertaccini, A., Lee, I.-M., Davis, R. E., and Clark, M. F. 1996. Differentiation and classification of aster yellows and related European phytoplasmas. Phytopathol. Mediterr. 35:33-42.

94. Vibio, M., Bertaccini, A., Lee, I.-M., Davis, R. E., Minucci, C., and Milne, R. G. 1994. Etiology of lettuce yellows in Italy: Genetic characterization of associated mycoplasmalike organisms. Phytopathol. Mediterr. 33:179-186.

95. Yoshikada, N., Nakamura, H., Shashi, N., Kubono, T., Katsube, K., Shoji, T., and Takahashi, T. 1994. Amplification and nucleotide sequences of ribosomal protein and 16S rRNA genes of mycoplasma-like organism associated with paulownia witches'-broom. Ann. Phytopathol. Soc. Jpn. 60:569-575.

96. Zhu, S. F., Lee, I.-M., Gundersen, D. E., Zhang, C. L., and Hadidi, A. 1996. Phytoplasmas associated with cherry lethal yellows and jujube witches'-broom in China represent a new Candidatus subspecies level Taxon. IOM Lett. 4:218.

97. Zreik, L., Carle, P., Bove, J. M., and Garnier, M. 1995. Characterization of the mycoplasmalike organism associated with witches'-broom disease of lime and proposition of a Candidatus taxon for the organism, "Candidatus Phytoplasma aurantiforlia”. Int. J. Syst. Bacteriol. 45:449-453. 